\title{
Effects of bromocriptine on serum prolactin levels, pituitary weight and immunoreactive prolactin cells in estradiol-treated ovariectomized rats: an experimental model of estrogen- dependent hyperprolactinemia
}

M.F. Ribeiro ${ }^{1}$, P.M. Spritzer ${ }^{1,2}$, L.M. Barbosa-Coutinho ${ }^{3}$, M.C. Oliveira ${ }^{3}$ M.A. Pavanato ${ }^{1}$, I.S.B. Silva ${ }^{1}$ and F.M. Reis ${ }^{1,2}$
${ }^{1}$ Departamento de Fisiologia, ${ }^{2}$ Unidade de Endocrinologia Ginecológica, Hospital de Clínicas de Porto Alegre, Universidade Federal do Rio Grande do Sul, and ${ }^{3}$ Departamento de Patologia, Fundação Faculdade Federal de Ciências Médicas de Porto Alegre, 90050-170 Porto Alegre, RS, Brasil
Correspondence

P.M. Spritzer

Departamento de Fisiologia

Universidade Federal

do Rio Grande do Sul

Rua Sarmento Leite, 500

90050-170 Porto Alegre, RS

Brasil

Fax: 55 (051) 226-7191

Presented at the XI Annual Meeting of the Federação de Sociedades de Biologia Experimental, Caxambu,

MG, Brasil, August 21-24, 1996

Research supported by FINEP (No. 66.91.0509.00) and CNPq (No. 520107/94-2).

Received April 19, 1996 Accepted November 4, 1996

\begin{abstract}
The present study was designed to assess the effects of bromocriptine, a dopamine agonist, on pituitary wet weight, number of immunoreactive prolactin cells and serum prolactin concentrations in estradioltreated rats. Ovariectomized Wistar rats were injected subcutaneously with sunflower oil vehicle or estradiol valerate $\left(50\right.$ or $300 \mu \mathrm{g} \mathrm{rat}^{-1}$ week $\left.^{-1}\right)$ for 2,4 or 10 weeks. Bromocriptine $\left(0.2\right.$ or $0.6 \mathrm{mg} \mathrm{rat}^{-1}$ day $\left.^{-1}\right)$ was injected daily during the last 5 or 12 days of estrogen treatment. Data were compared with those obtained for intact control rats. Administration of both doses of estrogen increased serum prolactin levels. No difference in the number of prolactin cells in rats treated with $50 \mu \mathrm{g}$ estradiol valerate was observed compared to intact adult animals. In contrast, rats treated with $300 \mu \mathrm{g}$ estradiol valerate showed a significant increase in the number of prolactin cells $(\mathrm{P}<0.05)$. Therefore, the increase in serum prolactin levels observed in rats treated with $50 \mu \mathrm{g}$ estradiol valerate, in the absence of morphological changes in the pituitary cells, suggests a "functional" estrogen-induced hyperprolactinemia. Bromocriptine decreased prolactin levels in all estrogen-treated rats. The administration of this drug to rats previously treated with $300 \mu \mathrm{g}$ estradiol valerate also resulted in a significant decrease in pituitary weight and number of prolactin cells when compared to the group treated with estradiol alone. The general antiprolactinemic and antiproliferative pituitary effects of bromocriptine treatment reported here validate the experimental model of estrogen-induced hyperprolactinemic rats.
\end{abstract}

Key words

- Prolactin levels

- Pituitary growth

- Immunoreactive prolactin cells

- Bromocriptine

- Estrogen 
Estrogen is known to have a stimulatory role in prolactin synthesis and release $(1,2)$. This steroid also induces pituitary tumors, depending on the experimental model and dose $(3,4)$. Dopamine, acting via its specific receptor in the anterior pituitary, tonically inhibits pituitary prolactin secretion and lactotroph proliferation (5-7). On the other hand, estradiol appears to be a potent antidopaminergic agent in vivo. (8) Bromocriptine (2-bromo- $\alpha$-ergocryptine, a dopamine agonist) has been used to examine the neuroendocrine mechanism of dopamine that controls prolactin secretion in vivo. In addition, dopamine agonist therapy for pituitary prolactinomas results in the reduction of prolactin secretion and tumor regression $(9,10)$.

There are only a few animal models available which are sensitive to dopamine agonists, such as the SMtTW tumor, a spontaneous prolactin-secreting transplantable tumor (4), and some studies using estrogen-induced hyperprolactinemia and pituitary enlargement (3,11-15). These studies did not report which doses and duration of in vivo estrogen administration are required to promote prolactin hypersecretion without pituitary enlargement or if bromocriptine effects on prolactin levels and lactotroph proliferation may vary with different schedules of estrogen treatment.

Table 1 - Effect of the administration of bromocriptine, a dopamine agonist, on pituitary wet weights of intact or ovariectomized rats treated with estradiol valerate.

Results are reported as mean \pm SEM. The number of animals is given in parentheses. $\mathrm{BCP}$, Bromocriptine. ${ }^{\mathrm{a} P}<0.05$ versus intact rats (Duncan's test); ${ }^{*} \mathrm{P}<0.05$ versus estradiol (t-test)

\begin{tabular}{|c|c|c|c|}
\hline $\begin{array}{l}\text { Estradiol } \\
\text { (dose rat }{ }^{-1} \text { week }^{-1} \text { ) }\end{array}$ & $\begin{array}{l}\text { Pituitary weight } \\
\text { (mg) }\end{array}$ & $\begin{array}{c}\text { Estradiol }+ \text { BCP } \\
\left(\text { dose BCP rat }{ }^{-1} \text { day }^{-1}\right)\end{array}$ & $\begin{array}{l}\text { Pituitary weight } \\
\text { (mg) }\end{array}$ \\
\hline Intact rats & $10.1 \pm 0.5(9)$ & & \\
\hline $50 \mu \mathrm{g}, 2$ weeks & $10.2 \pm 0.4(8)$ & $0.2 \mathrm{mg}, 5$ days & $10.61 \pm 1.5(5)$ \\
\hline $50 \mu \mathrm{g}, 4$ weeks & $11.3 \pm 0.5(5)$ & $0.6 \mathrm{mg}, 12$ days & $8.10 \pm 1.2^{*}(5)$ \\
\hline $50 \mu \mathrm{g}, 10$ weeks & $13.75 \pm 0.68^{a}(10)$ & & \\
\hline $300 \mu \mathrm{g}, 2$ weeks & $13.5 \pm 0.9^{a}(8)$ & $0.6 \mathrm{mg}, 12$ days & $9.26 \pm 0.42^{*}(8)$ \\
\hline $300 \mu \mathrm{g}, 4$ weeks & $15.1 \pm 0.5^{a}(8)$ & $0.6 \mathrm{mg}, 12$ days & $10.69 \pm 0.55^{*}(8)$ \\
\hline $300 \mu \mathrm{g}, 10$ weeks & $14.3 \pm 1.3^{a}(10)$ & $0.6 \mathrm{mg}, 12$ days & $9.58 \pm 0.8^{*}(10)$ \\
\hline
\end{tabular}

The present study was designed to assess the effects of bromocriptine on pituitary wet weight, number of prolactin cells and serum prolactin levels in ovariectomized animals subacutely or chronically stimulated with estrogen, in order to validate an experimental model for the study of the interaction between estrogen and dopamine in controlling prolactin secretion and lactotroph proliferation in vivo. Data were compared with those obtained for intact or ovariectomized control groups.

Ninety-four female Wistar rats, 3 months old, were maintained under conditions of controlled light and temperature with free access to water and standard rat chow. Rats were bilaterally ovariectomized under light ether anesthesia except for nine intact female rats which were used as a control group. All procedures used on the rats were performed according to the NIH Guide to the Care and Use of Laboratory Animals. The rats were injected subcutaneously with sunflower oil vehicle or estradiol valerate (Berlimed-Schering), 50 or $300 \mu$ rat $^{-1}$ week $^{-1}$ for 2, 4 or 10 weeks. Bromocriptine (Sandoz) was injected daily $\left(0.2\right.$ or $\left.0.6 \mathrm{mg} \mathrm{rat}^{-1} \mathrm{day}^{-1}\right)$ during the last 5 or 12 days of estrogen treatment.

Twenty-four hours after the last hormone or vehicle injection, rats were decapitated, trunk blood samples were collected, and serum was harvested and stored at $-20^{\circ} \mathrm{C}$ until assayed for prolactin by a double-antibody radioimmunoassay. Pituitary glands were removed immediately after decapitation and wet weights were determined with an electronic balance. Pituitary glands were placed in formalin and processed for prolactin immunohistochemistry as previously described $(13,16)$. Briefly, the antiserum used was provided by the National Institute of Arthritis, Diabetes, and Digestive and Kidney Diseases (NIADDK). Rat anti-prolactin antibody produced in rabbits was used at 1:2000 dilution. After inhibiting endogenous peroxidase with $1 \%$ methanol- $\mathrm{H}_{2} \mathrm{O}_{2}$, sections 
were treated with normal goat serum for 30 min to reduce nonspecific binding. The primary antiserum was applied for overnight incubation, treated with biotin anti-rabbit IgG for $30 \mathrm{~min}$ and finally incubated with the avidin-biotin peroxidase complex (Vector, Burlingame, CA) for $60 \mathrm{~min}$. Diaminobenzidine (DAB) (Serva, Heidelberg) was used for $5 \mathrm{~min}$ as the chromogen. Controls consisted of 2 sections of normal rat pituitary. One section was processed exactly as done for the experimental sections (positive control) and the other, in which the primary antibody was omitted, was used as the negative control. Rinsing with phosphate buffered saline was performed after each step.

Two hundred nucleated cells were counted at $\mathrm{X} 400$, using a $1-\mathrm{mm}^{2}$ grid in the microscope eyepiece, and the number of prolactin-containing cells was recorded. Cells were independently counted by 3 observers. The data were tabulated, the average count for each anterior pituitary was calculated and the result was reported as percent of cells containing prolactin in relation to total cellularity.

Serum prolactin content was measured by a double-antibody radioimmunoassay using materials kindly provided by the NIADDK. Prolactin was radioiodinated by the chloramine T method. NIADDK rat prolactin RP-3 was used as the standard. Assay sensitivity was $2 \mathrm{ng} / \mathrm{ml}$ and the intra- and interassay coefficients of variation were $8.6 \%$ and $12 \%$, respectively.

Statistical analysis was performed by either the Student $t$-test or by analysis of variance, followed by Duncan's multiple range test for the comparisons of multiple means. A $\mathrm{P}$ value $<0.05$ was considered to be statistically significant.

Table 1 shows the pituitary weights of intact and ovariectomized rats injected with estradiol valerate ( 50 or $300 \mu \mathrm{g} /$ week) alone or in combination with bromocriptine. No difference in mean pituitary weight was observed in rats treated with estradiol $(50 \mu \mathrm{g})$
Table 2 - Serum prolactin levels of intact or ovariectomized rats treated with estradiol valerate alone or in combination with bromocriptine.

Results are reported as mean \pm SEM. The number of animals is given in parentheses $\mathrm{BCP}$, Bromocriptine. ${ }^{\mathrm{P} P}<0.05$ versus intact rats (Duncan's test); ${ }^{*} \mathrm{P}<0.05$ versus estradiol (t-test).

\begin{tabular}{lrcr}
\hline $\begin{array}{l}\text { Estradiol } \\
\text { (dose rat }{ }^{-1} \text { week }^{-1} \text { ) }\end{array}$ & $\begin{array}{c}\text { Prolactin levels } \\
(\mathrm{ng} / \mathrm{ml})\end{array}$ & $\begin{array}{c}\text { Estradiol }+\mathrm{BCP} \\
\left(\text { dose BCP rat }^{-1} \text { day }^{-1}\right)\end{array}$ & \multicolumn{1}{c}{$\begin{array}{c}\text { Prolactin levels } \\
(\mathrm{ng} / \mathrm{ml})\end{array}$} \\
\hline Intact rats & $9.11 \pm 0.45(9)$ & & \\
$50 \mu \mathrm{g}, 2$ weeks & $39.70 \pm 3.60^{\mathrm{a}}(5)$ & $0.2 \mathrm{mg}, 5$ days & $4.41 \pm 0.65^{*}(5)$ \\
$50 \mu \mathrm{g}, 4$ weeks & $80.10 \pm 18.3^{\mathrm{a}}(5)$ & $0.6 \mathrm{mg}, 12$ days & $28.04 \pm 2.60^{*}(4)$ \\
$50 \mu \mathrm{g}, 10$ weeks & $83.60 \pm 23.6^{\mathrm{a}}(8)$ & & \\
$300 \mu \mathrm{g}, 2$ weeks & $335.9 \pm 96.1^{\mathrm{a}}(9)$ & $0.6 \mathrm{mg}, 12$ days & $19.65 \pm 3.40^{*}(7)$ \\
$300 \mu \mathrm{g}, 4$ weeks & $290.6 \pm 51.0^{\mathrm{a}}(8)$ & $0.6 \mathrm{mg}, 12$ days & $32.90 \pm 5.40^{*}(8)$ \\
$300 \mu \mathrm{g}, 10$ weeks & $100.6 \pm 22.0^{\mathrm{a}}(8)$ & $0.6 \mathrm{mg}, 12$ days & $7.92 \pm 2.70^{*}(10)$
\end{tabular}

for 2 or 4 weeks compared to intact adult animals. Only rats treated for 10 weeks showed a significant increase in pituitary weight $(\mathrm{P}<0.05)$. In contrast, rats treated with $300 \mu \mathrm{g}$ estradiol valerate showed a significant increase in pituitary weight as early as at 2 weeks of treatment $(\mathrm{P}<0.05)$. Bromocriptine, at the higher dose, significantly decreased the pituitary weights of all groups studied $(\mathrm{P}<0.05)$ when compared to the respective control rats treated with the same dose of estradiol valerate alone.

Table 2 illustrates the serum prolactin levels of intact rats and rats treated with estradiol alone or in combination with bromocriptine. Estrogen treatment $(50$ or 300 $\mu \mathrm{g} /$ week) for 2, 4 or 10 weeks significantly increased serum prolactin levels. The addition of bromocriptine to the treatment with estradiol valerate resulted in a significant decrease in serum prolactin levels when compared to the respective control group treated with estrogen alone.

Figure 1A shows the percentage of immunoreactive prolactin cells in ovariectomized rats subacutely or chronically treated with estradiol valerate $(50 \mu \mathrm{g})$ or vehicle. When these groups were compared to intact control rats, only ovariectomized rats without hormonal treatment presented a significantly lower number of prolactin cells. No difference in the percentage of lactotrophs 
Figure 1 - Effects of estradiol valerate alone or in combination with bromocriptine on the percent of immunoreactive prolactin cells in ovariectomized rats. Data are reported as percent of prolactin immunopositive cells in relation to those observed in intact rats (mean \pm SEM). The number of animals is given in parentheses. A, Rats were injected with vehicle $(O V X)$ or estradiol valerate (EV) $\left(50 \mu \mathrm{g} \mathrm{rat}^{-1}\right.$ week $^{-1}$ ) for 2, 4 or 10 weeks. $B$, Rats were injected with EV (300 $\mu$ rat $^{-1}$ week $^{-1}$ ) for 2, 4 or 10 weeks. EV + BCP, EV $(300 \mu \mathrm{g}$ rat $^{-1}$ week $^{-1}$ ) plus bromocriptine (0.6 $\mathrm{mg} \mathrm{rat}^{-1}$ day $^{-1}$ ), during the last 12 days of estrogen treatment. a $<<0.05$ compared to intact rats (Duncan's test) ${ }^{*} P<0.05$ compared to EV (300 $\mu \mathrm{g} \mathrm{rat}{ }^{-1}$ week $^{-1}$ ) (t-test). ${ }^{\mathrm{b}} \mathrm{P}<0.05$ compared to EV (50 and $300 \mu \mathrm{g}$ rat $^{-1}$ week $^{-1}$ ) and EV + BCP groups (Duncan's test).
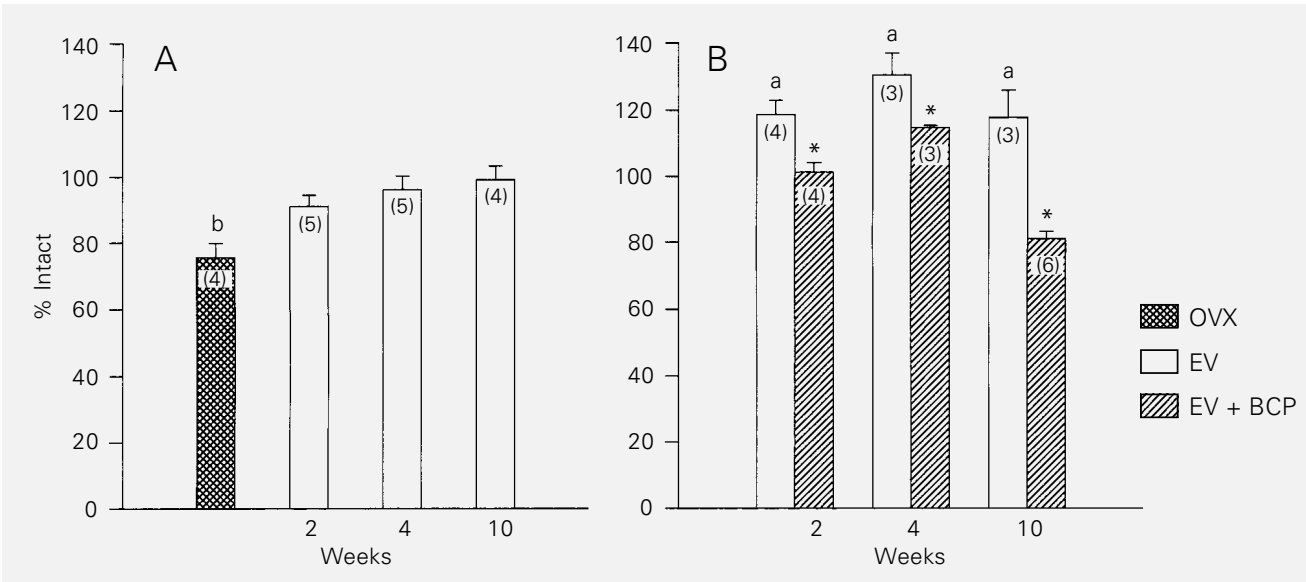

was observed in rats treated with estradiol valerate $(50 \mu \mathrm{g})$ for 2,4 or 10 weeks. In contrast, all rats treated with $300 \mu \mathrm{g}$ estradiol valerate for 2, 4 or 10 weeks presented a significant increase in the number of prolactin cells when compared to the intact control group (Figure 1B). As shown in Figure 1B, subsequent administration of bromocriptine to the rats treated with the highest dose of estrogen resulted in a significant reduction in the percentage of immunoreactive prolactin cells.

Estrogen administration to ovariectomized rats resulted in pituitary gland enlargement and in an increase in immunoreactive prolactin cells only after long-term treatment with $50 \mu \mathrm{g} / \mathrm{week}$ or at the higher dose $(300 \mu \mathrm{g})$, after all periods of time studied. Therefore, the increase in serum prolactin levels before morphological changes are observed in rats subacutely treated with the dose of $50 \mu \mathrm{g}$ estradiol valerate suggests a "functional" estrogen-induced hyperprolactinemia. This state of "functional hyperprolactinemia", which is similar to human idiopathic hyperprolactinemia (17), is a suitable model for the study of the neuroendocrine mechanisms of prolactin secretion, with the serum prolactin levels being taken as an example in the present study.

Thus, our findings obtained under different experimental conditions of estrogen administration to ovariectomized rats indicate two states of estrogen-dependent hyperpro- lactinemia: a functional hyperprolactinemia and a hyperprolactinemia associated with pituitary enlargement and lactotroph proliferation.

The present data show that bromocriptine decreased serum prolactin levels under all experimental conditions, even when no pituitary enlargement was observed. Using increasing doses of bromocriptine in estrogentreated rats, we have recently reported that the effect of bromocriptine in reducing the number of immunoreactive lactotrophs was observed only after long-term estrogen treatment including bromocriptine administration for 12 days (16). No difference was observed when bromocriptine was administered for the last 5 days of short-term estrogen treatment, suggesting that the duration of bromocriptine treatment required to detect a change in the number of lactotrophs by immunohistochemistry should be longer than 5 days (16). In the present study, we demonstrated a decline in lactotroph proliferation after only two weeks of estrogen treatment when bromocriptine was administered for 12 days. Our experiments do not address the question of the mechanisms underlying the different responses of prolactin cell proliferation to bromocriptine. However, it will be interesting to determine whether other schedules of concomitant administration of estrogen and bromocriptine as well as the association with other steroidal hormones have 
the same effects.

In conclusion, the present report describes a useful experimental model in which hypotheses concerning the mechanisms of action of estradiol in the induction of prolactin hypersecretion, pituitary enlargement and lactotroph proliferation can be tested. The general antiprolactinemic and antiproliferative pituitary effects of bromocriptine treatment reported here validate this model of estrogen-induced hyperprolactinemic rats. Further studies are needed to define the ex- act role of dopamine and dopamine agonists at the molecular level in hyperprolactinemic states and their connection with steroidal hormones.

\section{Acknowledgments}

The authors would like to thank the staff of the Laboratory of Neuroendocrinology, Faculty of Medicine of Ribeirão Preto, University of São Paulo, for providing goat antirabbit gammaglobulin.

\section{References}

1. Voogt JL, Chen CL \& Meites J (1970). Serum and pituitary prolactin levels before, during and after puberty in female rats. American Journal of Physiology, 218: 396-399.

2. Chen CL \& Meites J (1970). Effects of estrogen and progesterone on serum and pituitary prolactin levels in ovariectomized rats. Endocrinology, 86: 503-505.

3. Lloyd HM, Meares JD \& Jacobi J (1975). Effects of oestrogen and bromocriptine on in vivo secretion and mitosis in prolactin cells. Nature, 255: 497-498.

4. Schussler N, Farnoud R, Rauch C, Roche $M$, Berthet $M$, Thomas F, Peillon F \& Bayet MC (1994). Effect of the slow-release formulation of somatuline (BIM 23014) on estrogen-induced hyperprolactinemia and lactotroph hyperplasia in the female rat. Neuropeptides, 26: 399-404.

5. Foord SM, Peters JR, Dieguez C, Scanlon MF \& Hall R (1983). Dopamine receptors on intact anterior pituitary cells in culture: functional association with the inhibition of prolactin and thyrotropin. Endocrinology, 112: 1567-1577.

6. Trouillas J, Chevallier P, Claustrat B Hooghe-Peters E, Dubray C, Rousset B \& Girod C (1994). Inhibitory effects of the dopamine agonists quinagolide (CV 205502) and bromocriptine on prolactin secretion and growth of SMtTW pituitary tumours in the rat. Endocrinology, 134: 401-410.
7. Friedman E, Adams EF, Hoog A, Gejman PV, Carson E, Larsson C, De Marco L, Werner S, Fahlbush R \& Nordenskjold M (1994). Normal structural dopamine type 2 receptor gene in prolactin-secreting and other pituitary tumors. Journal of Clinical Endocrinology and Metabolism, 78: 568574.

8. Ferland L, Labrie F, Euvrard C \& Raynaud J-P (1979). Antidopaminergic activity of estrogens on prolactin release at the pituitary level in vivo. Molecular and Cellular Endocrinology, 14: 199-204.

9. Chiodini PG, Liuzzi A, Cozzi R, Verde G, Oppizzi G, Dallabonzana D, Spelta B, Silvestrini F, Borghi G, Luccarelli G, Rainer E \& Horowski R (1981). Size reduction of macroprolactinomas by bromocriptine or lisuride treatment. Journal of Clinical Endocrinology and Metabolism, 53: 737-743.

10. Tindall GT, Kovacs K, Horvath E \& Thorner MO (1982). Human prolactin-producing adenomas and bromocriptine: A histologic, immunocytochemical, ultrastructural, and morphometric study. Journal of Clinical Endocrinology and Metabolism, 55: 1178-1183.

11. Lyle SF, Wright K \& Collins DC (1984). Comparative effects of tamoxifen and bromocriptine on prolactin and pituitary weight in estradiol-treated male rats. Cancer, 53: 1473-1477.

12. Casanueva F, Cocchi D, Locatelli V, Flauto C, Zambotti F, Bestetti G, Rossi GL \& Müller E (1982). Defective central nervous system dopaminergic function in rats with estrogen-induced pituitary tumours, as assessed by plasma prolactin concentrations. Endocrinology, 110: 590-599.
13. Oliveira MC, Spritzer PM, Poy M, Corone AX, Dahlem N, Moraes JT \& BarbosaCoutinho LM (1993). Progestin effects on prolactin secretion and on immunoreactive prolactin cells in estradiol-treated ovariectomized rats. Hormone and Metabolic Research, 25: 600-602.

14. Phelps CJ \& Himer WC (1988). Effects of bromocriptine on prolactin cellular hypertrophy, proliferation and secretory activity in diethylstilbestrol-induced pituitary tumors. Molecular and Cellular Endocrinology, 58: 137-148.

15. McComb DJ, Hellmann $P$, Thorner MO, Scott D, Evans WS \& Kovacs K (1986). Morphologic effects of bromocriptine on spontaneously occurring pituitary prolactin-cell hyperplasia in old Long-Evans rats. American Journal of Pathology, 122: 7-16.

16. Spritzer PM, Ribeiro MF, Oliveira MC Barbosa-Coutinho LM, Silva ISB, Dahlem N, Cericatto R \& Pavanato MA (1996). Effects of tamoxifen on prolactin levels, pituitary immunoreactive prolactin cells and uterine growth in estradiol-treated ovariectomized rats. Hormone and Metabolic Research, 28: 171-176.

17. Paradisi R, Grossi G, Pintore A, Venturol S, Porcu E, Capelli M \& Flamigni C (1991). Evidence for a pathological reduction in brain dopamine metabolism in idiopathic hyperprolactinemia. Acta Endocrinologica, 125: 246-252 